\title{
MICROBIOLOGICAL BIODIVERSITY IN POULTRY AND PADDY STRAW WASTES IN COMPOSTING SYSTEMS
}

\author{
Sunita Devii ${ }^{1}$ C.R. Sharma ${ }^{1 *}$, Kamlesh Singh ${ }^{2}$ \\ ${ }^{1}$ Department of Microbiology, College of Basic Sciences, CSK HPKV, Palampur-176062 India; ${ }^{2}$ Department of Statistics, \\ Mathematics \& Physics, College of Basic Sciences, CSKHPKV Palampur 176062-India.
}

Submitted: September 12, 2010; Approved: August 30, 2011.

\begin{abstract}
Immense quantity of waste is generated in association with poultry meat egg and crop production. The potential risks due to disposal of these wastes are magnified as a result of dense refinement of poultry production and the decreasing amount of land available for waste disposal. The study aims at studying the microbiological biodiversity of poultry waste and paddy straw based co-composting system. The predominant microflora of the poultry manure were bacteria, fungi, enteric bacteria and spore forming bacteria whose population was high at the initiation of composting but decreased significantly as the compost approached maturity. The initial load of inherent enteric groups of bacteria in poultry waste, that also includes some pathogenic ones, is considerably reduced and some new vital groups contributed to compost quality as the microbiological biodiversity sets in the system and becomes stable. Major fraction of nitrogen of poultry waste was subjected to ammonia volatilization and a fraction of it conserved by cocomposting it in conjunction with wastes having low nitrogen contents. In the treatment $\mathrm{T}_{1}$ and $\mathrm{T}_{5}$, where poultry manure and paddy straws alone were composted, 60 and 30 percent of organic carbon, respectively, was lost over a period of six months. Whereas in treatments $T_{2}, T_{3}$ and $T_{4}$, poultry manure and paddy straw were co-composted in the ratio of $3: 1,2: 2$ and 1:3, respectively, 51.4,45.0 and 37.0 percent of carbon, respectively, was lost during decomposition. The $\mathrm{C}: \mathrm{N}$ ratio in all the treatments decreased significantly to 18.3 for $\mathrm{T}_{1}, 24.7$ for $\mathrm{T}_{2}, 27.0$ for $\mathrm{T}_{3}, 34.9$ for $\mathrm{T}_{4}$ and 38.5 for $\mathrm{T}_{5}$ at the end of composting period.
\end{abstract}

Key words: composting, microbial succession, organic waste, microbiological biodiversity

\section{INTRODUCTION}

Composting, a natural biological process, is the controlled decay of organic matter in a warm moist environment by action of bacteria, fungi and other organisms (22), under conditions favourable for them. The process can either be anaerobic or aerobic, but it is much faster and less odourferous if done aerobically. Composting provides a means of recycling solid wastes and has the potential to manage most of the organic material in the waste stream. The organic waste materials mainly of animal and plant origin are potential source of organic matter and plant nutrient (1). The benefits derived from

*Corresponding Author. Mailing address: Department of Microbiology, College of Basic Sciences, CSK HPKV, Palampur-176062 India.; Tel.: +91-9418093893.; E-mail: sunitachamba@yahoo.co.in 
the utilization of these organic materials range from improvement of soil fertility to a reliable means of waste disposal. Processing of organic waste by compost provides an opportunity to reduce its bulk, odour as well as increasing the nutritive value (9).

As a result of energy crisis and associated detrimental effects on soil health and environmental problems, there is a renewed interest in the organic manures all over the world which forms the basis of sustainable agriculture. One of such potential residues likely to get importance in Indian agriculture is poultry manure which is as such a valuable resource of plant nutrition but a potential source of pathogenic microorganisms too. Although poultry manure is a nitrogen rich material and is of economic importance as fertilizer, feed supplement and energy source, the poor management not only damaging the crops but also leads to pollution of water resources (20). Nitrate leaching and accumulation of waste components such as phosphorus, potassium and others in the soil are possible impacts of land application of poultry waste (8). In addition to this eutrophication- related impacts like fish mortality, human and animal health hazards, high chlorine concentrations, pathogen presence and other nuisances like flies, odours and colour may result from traditional disposal of poultry waste (14). Moreover, the high rate of application of poultry manure for supplying $\mathrm{N}$-requirements to crops has been shown to have adverse effect on a variety of crops and grasses. The decreased yield of the crops associated with high rate of poultry waste application may be attributed to the toxic concentration of ammonia, nitrate, nitrite and soluble salts (11). Even phosphorus is known to accumulate in soil treated with poultry litter (12) which causes imbalance in $\mathrm{N}$ : P ratio of the soil and also results in the increased organic matter content in the upper layer of the soil and also adversely alters some soil physical properties.

Inspite of this, poultry manure is a good fertilizer due to its high carbon and nitrogen content and low $\mathrm{C}: \mathrm{N}$ ratio. High water content make it difficult to handle fresh poultry manure and can not be applied to the crops due to its caustic effects on foliage, in addition to adverse environmental effects on soil, water and air. Poultry manure is treated to avoid unpleasant odours and to obtain a final product with a high dry matter content and stabilized with respect to organic matter. However, emissions from poultry mannure present soil and environmental problems caused by the loss of ammonia during storage. This leads to various consequences social unacceptability for the undesirable odour, environmental pollution and consistent losses of nitrogen, a valuable nutritive element (19).

The composting of poultry manure produces a stabilized product that can be stored or spread on soil with little or no obnoxious odour, pathogens, weed seeds and fly breeding potential. Poultry manure composting has a high potential for ammonia volatilization because of its low $\mathrm{C}$ : $\mathrm{N}$ ratio. The loss of ammonia during composting of poultry manure not only reduces its agronomic value but also contributes to environmental pollution which also plays an important role in acid rain (5). This loss can be reduced by co-composting poultry manure with a material rich in organic carbon and deficient in nitrogen which is paddy straw in this study.

The ammonia volatilization can also be reduced by immobilisation of ammonium ions by co-composting poultry manure with carbon rich organic waste materials (15) and adsorption of ammonia and or ammonium ions using adsorbents such as zeolites and peat (26). The cost effective technologies that reduce ammonia loss during composting of poultry manure would have positive, economic and environmental benefits. Keeping in view, above facts, this study has been taken up to study the incidence of microorganisms associated with poultry manure and to follow their succession in different treatments at the different stages of composting.

\section{MATERIALS AND METHODS}

The present investigation was conducted in the Department of Microbiology, College of Basic Sciences, Chaudhary Sarvan Kumar Himachal Pradesh Krishi 
Vishvavidyalaya, Palampur, India. Paddy straw and poultry manure were procured from the Research Farm of the university and poultry Farm Banuri, Palampur, respectively. Poultry manure and paddy straw (dried and chopped to 3" size) were analysed for moisture content, total nitrogen, volatile and non-volatile solids. The experiment on co-composting of poultry manure and paddy straw was laid out in completely randomized block design (CRD) with five treatment combinations in plastic pots of $10 \mathrm{~kg}$ capacity as well as in composting pits of the size of $1 \mathrm{~m} \times 1 \mathrm{~m} \times 0.5 \mathrm{~m}$ and each treatment was quadruplicated. The data generated was statistically analysed using standard statistical procedures (24).

Table 1. Plan of experimentation

\begin{tabular}{|c|c|c|c|c|c|c|}
\hline Treatment & Detail of treatment & $\operatorname{Ash}(\%)$ & Organic matter $(\%)$ & Organic carbon $(\%)$ & Total nitrogen (\%) & C:N ratio \\
\hline $\mathrm{T}_{1}$ & PM alone(4) & 24.5 & 75.5 & 43.8 & 3.5 & 12.5 \\
\hline $\mathrm{T}_{2}$ & $\mathrm{PM}+\mathrm{PS}(3: 1)$ & 21.4 & 78.6 & 45.6 & 2.8 & 16.6 \\
\hline $\mathrm{T}_{3}$ & $\mathrm{PM}+\mathrm{PS}(2: 2)$ & 18.4 & 81.6 & 47.4 & 2.0 & 23.7 \\
\hline $\mathrm{T}_{4}$ & PM+PS (1:3) & 15.3 & 84.7 & 49.1 & 1.3 & 39.3 \\
\hline $\mathrm{T}_{5}$ & PS alone (4) & 12.2 & 87.8 & 50.9 & 0.5 & 101.8 \\
\hline
\end{tabular}

PM- poultry manure; PS- Paddy straw

In the treatments $T_{1}$ and $T_{5}$, only poultry manure and paddy straw, respectively, were taken. Whereas, in treatments $\mathrm{T}_{2}, \mathrm{~T}_{3}$ and $\mathrm{T}_{4}$ poultry manure and paddy straw were mixed in the ratio of $3: 1,2: 2$ and $1: 3$, respectively. These materials were thoroughly mixed and maintained at an appropriate moisture level throughout the course of composting over a period of six months and periodically analysed for some microbiological and chemical parameters.

\section{Microbiological studies}

The fungal, bacterial and actinomycetes population was estimated by standard plate count technique (27) using potato dextrose agar medium for fungi and nutrient agar medium for bacteria and actinomycetes. Diazotrophic and Enteric bacterial population was determined by the most probable number technique (4) by using Jensen's broth medium and lactose broth supplemented with $1.5 \mathrm{~g} /$ litre sodium taurocholate, respectively. Aerobic spore forming bacterial population was determined by the most probable number technique (4) by gradually heating compost samples initially at a low temperature of $45^{\circ} \mathrm{C}$ which was later raised to the boiling point slowly over a period of 90 minutes in a water bath. Algal and blue green algal populations were determined by most probable number technique using Bristol's and Pringsheim's medium, respectively $(2,4)$.

\section{Chemical analysis}

Moisture was determined by the method of AOAC (3). Volatile and non-volatile solids were determined by ignition method (13) by ashing the material in a muffle furnace (Secor, India) at $600^{\circ} \mathrm{c}$ for five hours. The loss in volatile solids was divided by a factor of 1.724 to calculate organic carbon content. Total nitrogen was determined by the conventional Kjeldahl method (18).

\section{RESULTS AND DISCUSSION}

\section{Bacterial population}

The bacterial population (Figure 1) decreased significantly right from the start till $6^{\text {th }}$ week of composting in all the treatments. Whereas, in the $10^{\text {th }}$ and $16^{\text {th }}$ week of composting, there was a sudden two fold increase and thereafter a slow but 
significant decrease in the population was observed. Population of $13 \times 10^{9}, 17 \times 10^{9}, 10 \times 10^{9}, 15 \times 10^{9}$ and $18 \times 10^{9} / \mathrm{g}$ of compost in treatments $\mathrm{T}_{1}, \mathrm{~T}_{2}, \mathrm{~T}_{3}, \mathrm{~T}_{4}$ and $\mathrm{T}_{5}$, respectively, was obtained at the end of composting period. Their population was maximum in $2^{\text {nd }}, 10^{\text {th }}$ and $16^{\text {th }}$ week of composting. The $2^{\text {nd }}$ increase in the $10^{\text {th }}$ and $16^{\text {th }}$ week may be attributed to the fact that the easily utilizable substrate for bacteria as a result of the fungal degradation of the composting material was available. These two maxima in bacterial population were reported to be coincinding with the first and final mesophilic phases of composting $(7,23)$. Bacteria and filamentous fungi appeared to be the main decomposers and their number ranged between $10^{8}-10^{9} / \mathrm{g}$, wherein the bacteria predominate $(10$, 21). It was also observed that in the initial stages of decomposition, bacteria and fungi seem to be the main colonizers and thereafter, the microbial population decreased gradually in the mature compost.

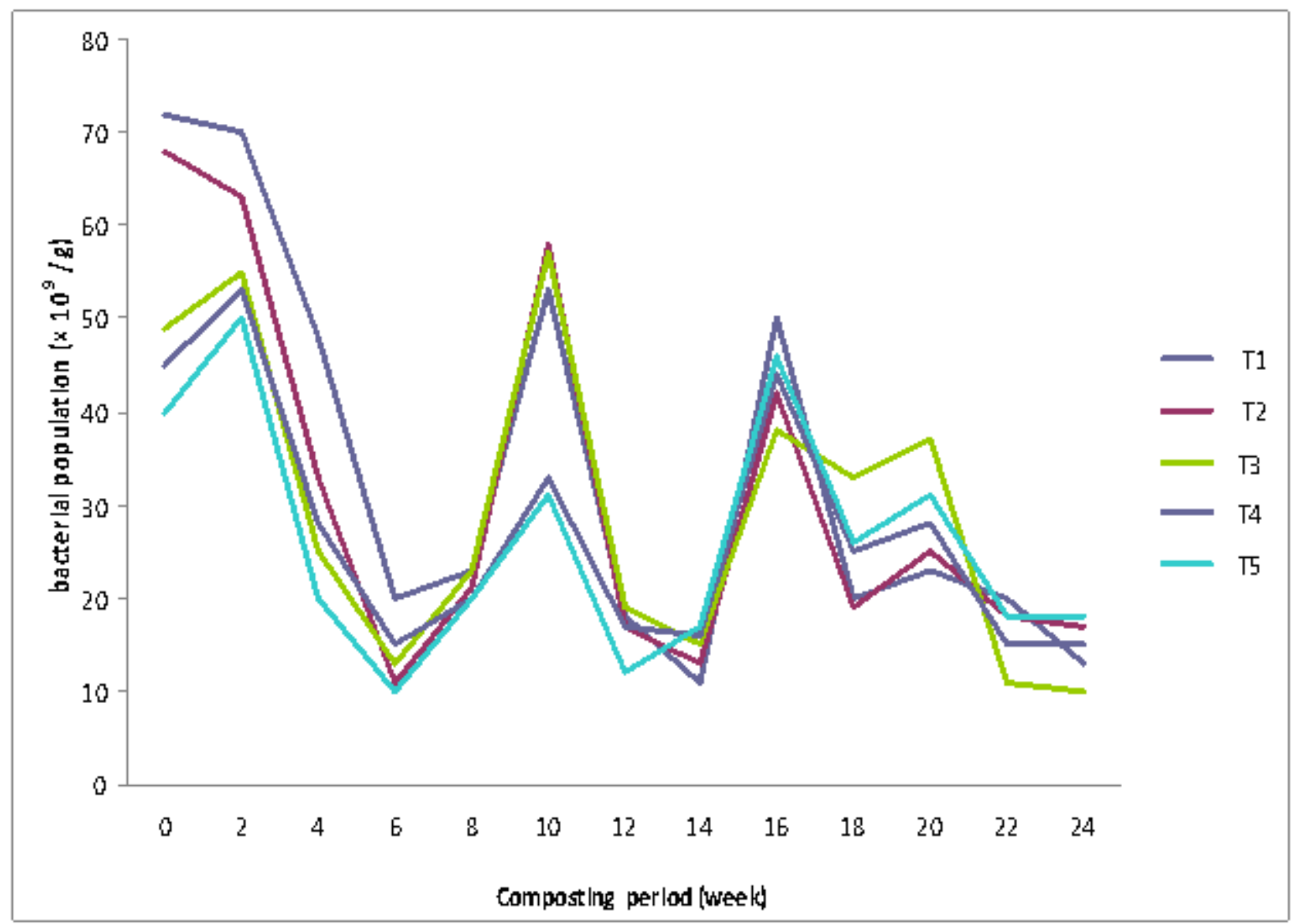

Figure 1. Effect of different treatments on the bacterial population $(\times 109 / \mathrm{g})$ during co-composting

\section{Enteric bacteria}

Since enteric bacterial population is an inherent micro flora of poultry manure there was a sudden two fold increase in the $10^{\text {th }}$ week, as the fungal population had released the secondary metabolites which served as carbon and energy source for this heterotrophic group of bacteria. After $10^{\text {th }}$ week when the compost was approaching maturity, the enteric population in all treatments started declining and ultimately stabilized in the mature compost at about $1 \%$ of their initial load present in the poultry manure. This is attributed to the fact that the microbial biodiversity has set in as the compost approached maturity (6). 


\section{Spore -forming bacteria}

Spore -forming bacterial population was quite high in the initial samples of poultry manure and survived in high numbers till the $18^{\text {th }}$ week of decomposition. This group remained as active colonizers of this ecosystem, thereby, showing some specialized physiological functions associated with it in the composting process. It is presumed that their physiological role as proteolytic organism was the factor behind their association throughout. This group started declining after $20^{\text {th }}$ week of composting where it has established itself at $1 / 3$ population density of the initial load. Their population was observed to be $10^{5}-10^{7}(21)$ and $8.1 \times 10^{4}$ spore formers /g of compost (17).

\section{Diazotrophic bacteria}

The population of Diazotrophic bacteria attained a minimum low level right from the start till $10^{\text {th }}$ week of decomposition and started increasing thereafter. It attained a low and steady level throughout the subsequent course of decomposition at a population level of about $20 \times 10^{4}$ diazotrophic cells / $\mathrm{g}$ of the compost. Since this is a slow growing group of bacteria, it could not compete with heterotrophic bacteria and fungi, predominated during the early phases of decomposition. Later on when the compost approached maturity and microbial diversity was set in, it established itself. A great variety and high number of diverse physiological groups including diazotrophic microorganisms establish themselves and are important for compost stabilization (6).

\section{Actinomycetes population}

At the initial stages of composting, their presence was not detected, except in treatment $\mathrm{T}_{1}$, containing poultry manure only. They started appearing in a low but detectable number at the $4^{\text {th }}$ week and could not establish substantially till the $10^{\text {th }}$ week of decomposition when other active groups of microorganisms started declining. As the compost approached maturity, they multiplied and established in a substantial proportion in comparison to other groups of microorganisms. Actinomycetes increased in number with time (10) and their number was $5.2 \times 10^{4} / \mathrm{g}$ in mature compost (17). It was observed that they established only when the microbiological biodiversity has set in. A great variety and high number of different physiological groups of micro organisms which also include actinomycetes play an important role for compost stabilisation (6).

\section{Fungal population}

The data presented in the (Figure 2) on the fungal population during the course of co-composting revealed that their population decreased as the proportion of poultry manure in the composting system decreases. This is evident because the poultry litter is a rich source of cellulosic materials, nitrogen and other nutrients supporting a very high population of fungi. The fungal population started declining after the $4^{\text {th }}$ week and followed by 2 nd maxima in it, in the $10^{\text {th }}$ week of decomposition. Thereafter, the fungi started declining in all the treatments and maintained at a low level of $2 \times 10^{6} \mathrm{cfu} / \mathrm{g}$ in the mature compost. Further, in the later stages, fungi along with actinomycetes were responsible for the destruction of long chain polysaccharides. After the $2^{\text {nd }}$ maxima in their population during $10^{\text {th }}$ week, irrespective of the treatments, fungi started declining, thereby, showing that the cellulosic material upon which they thrive got depleted and on the secondary metabolites, some diverse microbial groups started appearing (28). A further decline in the fungal population was also observed towards the maturity of compost (23). 


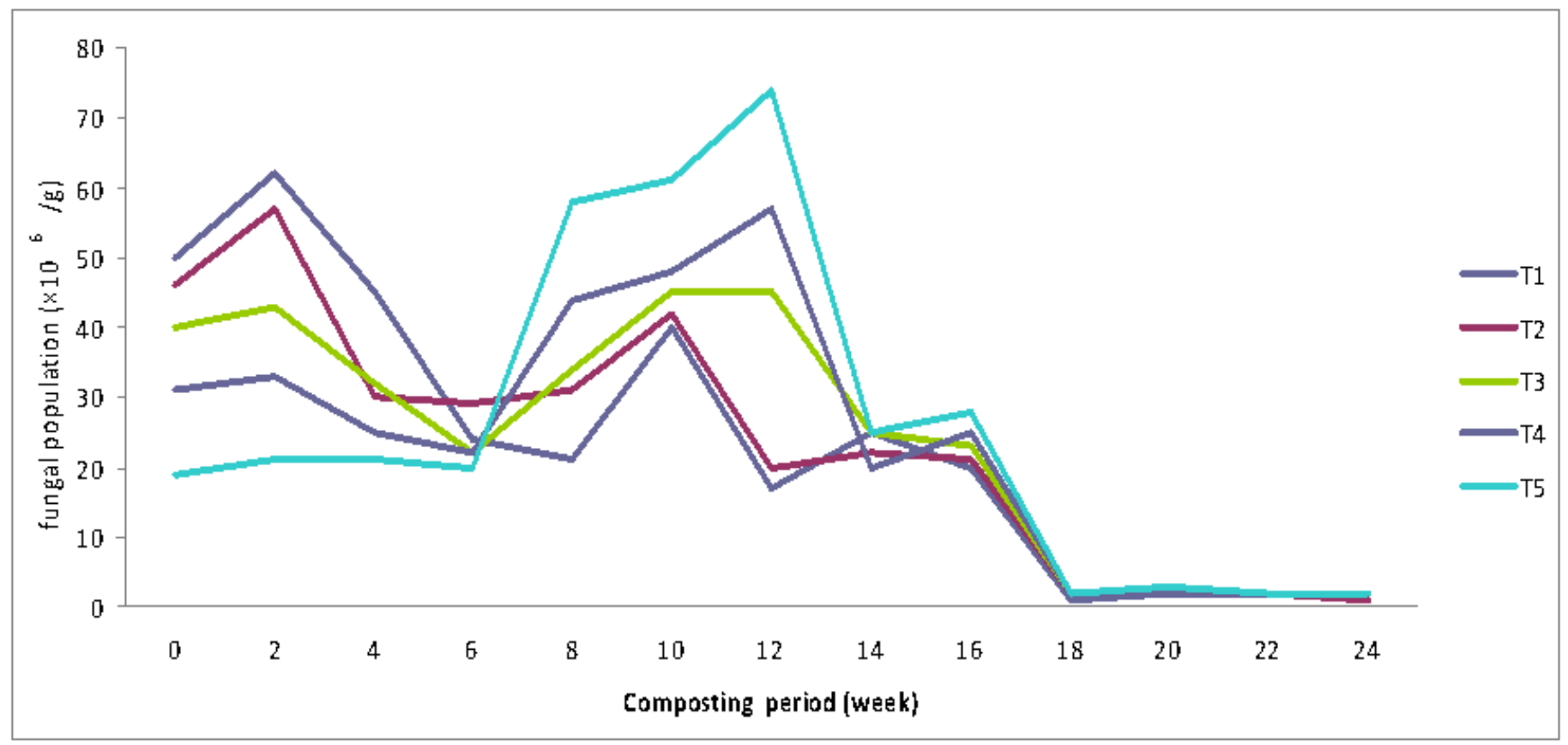

Figure 2. Effect of different treatments on the fungal population $\left(\times 10^{6} / \mathrm{g}\right)$ during co-composting

\section{Algal population}

Algal population could not be detected during the early stages of composting. However, on $8^{\mathrm{h}}$ week onwards, they started appearing significantly at a low density of about 100 cells/g of material in treatment $T_{1}$, containing poultry manure only. Their population remained almost stationary in $10^{\text {th }}$ and $12^{\text {th }}$ week and started showing statistically significant increasing trend after $14^{\text {th }}$ week of decomposition only in the treatments which contained poultry manure as an essential component (17) and a maximum population of about 500cells/g of composting material was observed in the $18^{\text {th }}$ week which significantly decreased towards the end of composting. In the finished product, as few as 100 to 200 cells/g of composting material were observed in different treatments. It seems that they are also the essential component of the microbiodiversitical equilibrium in the mature compost. Treatment $\mathrm{T}_{1}$ was significantly superior over rest of the treatments in the population However, $\mathrm{T}_{2}, \mathrm{~T}_{3}$ and $\mathrm{T}_{4}$ were statistically at par with each other and $\mathrm{T}_{5}$ was statistically inferior over rest of the treatments as far as their population is concerned.

\section{Blue green algae}

The effect of different treatments upon the blue green algal population depicted their absence till the $14^{\text {th }}$ week of decomposition. On the $14^{\text {th }}$ week onward, they started appearing at a very low population density and have become an integral part of the microbiological diversity of the mature and stabilized compost

\section{Chemical analysis}

Recovery of material: Recovery of material after the composting period increased as the proportion of paddy straw over poultry manure in the system increased. This is because paddy straw is a comparatively resistant material to microbial degradation. This is also evident from the fact that in treatments $T_{1}$ and $T_{5}$, which comprise of exclusively poultry manure and paddy straw respectively, the respective loss of organic matter over a period of six months, was 45 and $28 \%$ 
(Table1).

Organic carbon: Organic carbon content decreased with the increasing proportion of paddy straw in poultry manure in different treatments. At the end of composting, 60 and $30 \%$ of the organic carbon was lost in treatment $\mathrm{T}_{1}$ (containing poultry manure) and $\mathrm{T}_{5}$ (paddy straw alone), respectively (Table1). This can be explained in the light of the fact that poultry manure is a nutrient rich medium as compared to the paddy straw and hence subjected to a rapid microbial degradation. Organic carbon of poultry manure when composted alone for 90 and 180 days, a loss of $24 \%$ and $17 \%$ was observed ,respectively (16). However, a corresponding loss of $24 \%$ of organic carbon was observed from the poultry manure in a period of 90 days (Table1).

Total nitrogen: A substantial amount of nitrogen is lost from poultry manure as a result of ammonia volatilization and as high as $67 \%$ of it was lost within a short period of 45 days. Thereafter the loss was constant for a period of 135 days. However, a loss of $73 \%$ at the end of 180 days of composting was recorded. This is because the initial nitrogen of $3.5 \%$ in the original poultry manure is loosely bound to organic macromolecules and a fraction also exists in inorganic form which is easily subjected to ammonia volatilization losses. Since the material is rich in organic carbon too, any further loss of carbon would lead to ammonia volatilization. There was 44 $\%$ loss of nitrogen in composted poultry manure through ammonia volatilization (16).This study, further observed that the loss of nitrogen through ammonia volatilization decreased as the amount of paddy straw - a material rich in organic carbon and deficient in nitrogen, is increased over the decreasing amount of poultry manure in the composting material, which forms the basis of the investigation. It is because of the fact that a fraction of the nitrogen from the poultry manure which is subjected to ammonia volatilization becomes available for the microbiological immobilization in the paddy straw poultry manure co-composting system. Ammonia volatilization can be reduced by immobilization of
$\mathrm{NH}_{3}$ or $\mathrm{NH}^{4+}$ ions by co-composting poultry manures with carbon rich organic waste materials $(15,25)$. There was a little loss of $25 \%$ initial nitrogen from poultry manure in the treatment $\mathrm{T}_{4}$, containing $25 \%$ poultry manure and $75 \%$ paddy straw. In the treatment $\mathrm{T}_{5}$, containing paddy straw alone, there was a gradual build up of nitrogen during the course of decomposition which may be partly due to the activity of diazotrophic bacteria in a medium like paddy straw- deficient of nitrogen (Table1).

C: $\mathbf{N}$ ratio: The $C: \mathrm{N}$ ratio in the treatment $\mathrm{T}_{1}$ containing poultry manure only, increased from 12.5 to 34.0 in 45 days of composting which is attributed to the substantial loss of nitrogen during this period through ammonia volatilization. At 90, 135, and 180 days, it's $\mathrm{C}$ : $\mathrm{N}$ ratio came down to $27.2,19.0$ and 18.3, respectively which is attributed to the substantial loss of organic carbon during this period. In treatment $T_{5}$, containing paddy straw alone, the $\mathrm{C}$ : $\mathrm{N}$ ratio fell from 101.8 to 38.5 over a period of 180 days which is attributed to the slow rate of carbon loss from paddy straw as a result of decomposition and also partially due to the activity of diazotrophic bacteria under low nitrogen conditions. In treatments $T_{2}, T_{3}$ and $T_{4}$ containing different proportions of poultry manure and paddy straw the corresponding $\mathrm{C}$ : $\mathrm{N}$ ratio was 24.7, 27.0 and 34.9, respectively (Table1).

\section{CONCLUSIONS}

The predominant microflora of poultry manure was bacteria, fungi, enteric and spore forming bacteria whose population was $72 \times 10^{9} ; 50 \times 10^{6} ; 22 \times 10^{9}$ and $18 \times 10^{4}$, respectively per gram of the poultry manure at the initiation of composting. Their number decreased significantly to about $14.6 \times 10^{9}$ (bacteria); $1.6 \times 10^{6}$ (fungi); $18 \times 10^{9}$ (enteric bacteria) and $2.6 \times 10^{4}$ (spore forming bacteria) at the end of composting period of 180 days as the amount of poultry manure decreases over the paddy straw in the composting system. After the composting period of 180 days, $45 \%$ of the organic matter of 
the poultry manure and $26 \%$ of the paddy straw was lost during composting. As far as the organic carbon is concerned, $60 \%$ of the initial carbon of the poultry manure and $30 \%$ of the paddy straw was lost during decomposition. Whereas $67 \%$ of the initial nitrogen of poultry manure was lost via $\mathrm{NH}_{3}$ volatilization when composted alone and its total loss at the end of composting at 180 days was $73 \%$. But when decreasing amount of poultry manure was composted with increasing amount of paddy straw, the loss of nitrogen through $\mathrm{NH}_{3}$ volatilization proportionately decreased. In treatment $T_{5}$, containing paddy straw alone, there was slow and continuous gain of nitrogen. Therefore co-composting of poultry manure along with paddy straw in the proportion of $1: 3$ is more beneficial for crops as the availability of nitrogen is more.

\section{REFERENCES}

1. Adeniran,J. A.; Taiwo, L. B.; Sobulo, R. A. (2003). Effects of Organic wastes and methods of composting on compost maturity, nutrient composition of compost and yields of two vegetable crops. J. Sustain. Agric. 22, 95-101.

2. Allen, O. N. (1957). Experiments in Soil Bacteriology. $3^{\text {rd }}$ ed. Burgess Publishing Company, Minneapolis.pp 117

3. AOAC. (1970). Association of Official Analytical Chemists. Official Methods of Analysis. 11 ${ }^{\text {th }}$ ed. Washington, DC. pp.661-663.

4. APHA (1985). Standard Methods for the examination of water and waste water. $16^{\text {th }}$ edition, AWWA, WPCF, American Public Health Association, Washington, DC. p 666 - 676

5. ApSimon, H. M.; Kruse, M.; Bell, J. N. B. (1987). Ammonia emissions and their role in acid deposition. Atmos.environ 21, 1939-1946.

6. Beffa, T.; Blanc, M.; Marilley, L.; Fisher, J. L.; Lyons, P. F.; Aragno, M.; Lemmes, B. (1996). Taxonomic and metabolic biodiversity during composting. Sci. Compost. 1, 149-161.

7. Falcon, M. A.; Corominas, E.; Perez, M. C.; Perostelo, F. (1987). Aerobic bacterial populations and environmental factors involved in composting of agricultural land forest wastes. Biol. Wastes 20, 89-99.

8. Fontenot, J. P.; Smith, L. W.; Sultan, A. L. (1983). Alternative utilization of animal wastes. J. Ani. Sci. 57, 222-233.

9. Gray, K. R.; Briddlestone, A. J. (1981). The composting of Agricultural Wastes. In: B Steneho (ed) Biological husbandary. Butterworths publications, London, England, p. 99-112.

10. Hardy, G. S. J.; Sivasithamparam, K. (1989). Microbial, chemical and physical changes during composting of eucalyptus bark mixture.
Biol.and Fert. Soils 8(3), 260-270.

11. Hileman, L.H. (1965). Broiler litter as fertilizer. Arkansas Farm Res. 16, 6.

12. Hileman, L.H. (1973). Response of orchard grass to broiler litter and commercial fertilizer. Rep. Ser. 207. Arkansas Agricultural Experimental Station, University of Arkansas, Fayetteville, A.R.pp

13. Jackson, M.L. (1967). Organic matter determinations for soils. In: Soil Chemical Analysis. Prentice Hall of India. Private Limited, New Delhi, p. 205-226.

14. Loehr, R.C. (1968). Pollution implications of animal wastes-a forward orientated review. EPA 13040-07/68. U.S. Environmental Protection Agency, Washington, D.C.

15. Mahimairaja, S.; Bolan, N.S.; Hedley, M.; Macgregor, A.N. (1994). Losses and transformation of nitrogen during composting of poultry manure with different amendments: An incubation experiment. Bioresource Technol. 47, 265-273.

16. Mondini, C.; Chiumenti, R.; Borso, F.; Da, Leita, L.; Nobili, M. De. (1996). Changes during processing in the organic matter of composted and air dried poultry manure. Bioresource Technol. 55, 243-249.

17. Nodar, R.; Acea, M. J.; Caraballas, T. (1990). Microbial composition of poultry excreta. Biol. Wastes 33, 95-105.

18. Page, A.L. (1982). Methods of Soil Analysis. Part-II. Chemical and Microbiological properties. American Science Society of Agronomy, Inc. and Soil Science Society of America, Inc. Madison, Wisconsin, USA.pp

19. Piccnini, S.; Rossi, L.; Bonazzi, G.; Dall'Orso, G. (1995). The EmillaRomagna experiment in animal manure composting. Proceedings of International Symposium. The Science of composting, Bologna, Italy (in Press).

20. Pratt, P.F. (1979). Management restrictions in soil application of manure. J. Ani. Sci. 48, 134-143.

21. Ravina, M.D.; Acea, M.J.; Caraballas, T. (1989). Microbiological characterization of four composted urban refuses. Biol. Wastes 30, 89100 .

22. Salvator, K.; Sabee, W. E. (1995). Evaluation of fertilizer value and nutrient release from corn and soyabean residues under laboratory and green house conditions. Commu.Soil Sci. 48, 14-15.

23. Sedha, R.K.; Chahal, D.S.; Pandher, M.S. (1991). Microbial degradation of wheat straw in field I. Changes in microflora during decomposition. Indian J. Microbiol. 31, 301-307.

24. Snedecor, G.W.; Cochran, W.G. (1994) Statistical Methods. $8^{\text {Th }}$ ed. Oxford and IBH Publishing Co., Calcutta.pp

25. Thambirajah, J.J.; Zulkali, M.D.; Hashim, M.A. (1995). Microbiological and biochemical changes during composting of oil-palm empty fruit bunches: effect of nitrogen supplementation on the substrates. Bioresource Technol. 51, 133-144

26. Witter, E.; Kirchmann, H. (1989). Peat, zeolite and basalt as adsorbents of ammonical nitrogen during manure decomposition. Plant Soil 115, 43- 
Devi, S. et al.

52.

27. Wollum II, A.G. (1982). Cultural methods for soil microorganisms. In: Methods of Soil Analysis. Chemical and Microbiological properties.

C.A. Black (eds). American Society of Agronomy, Inc. Soil Science
Microbiological biodiversity in poultry and paddy straw wastes

Society of America, Inc. Publisher Madison, Wisconsin, USA, p.781-802

28. Young C.; Hudson, H.J. (1967). The fungi of wheat straw compost-II: Biological and physiological studies. Trans Br Mycol Soc 50, 667-677. 